Dawes, P. R. 1975: Reconnaissance of the Thule Group and underlying basement rocks between Inglefield Bredning and Melville Bugt, North Greenland. Rapp. Gronlands geol. Unders. 75, 34-38.

Dawes, P. R. 1976: 1:500 000 mapping of the Thule district, North-West Greenland. Rapp. Grønlands geol. Unders. 80, 23-28.

Escher, J. C. \& Stecher, O. 1978: Precambrian geology of Upernavik - Red Head region $\left(72^{\circ} 15^{\prime}-75^{\circ} 15^{\prime} \mathrm{N}\right)$, northern West Greenland. Rapp. Grønlands geol. Unders. 90, 23-26.

Frisch, T., Morgan, W. C. \& Dunning, G. R. 1978: Reconnaissance geology of the Precambrian Shield on Ellesmere and Coburg Islands, Canadian Arctic Archipelago. Pap. geol. Surv. Can. 78-1A, 135-138.

Larsen, O. \& Dawes, P. R. 1974: K/Ar and Rb/Sr age determinations on Precambrian crystalline rocks in the Inglefield Land-Inglefield Bredning region, Thule district, western North Greenland. Rapp. Grønlands geol. Unders. 66, 4-8.

Peary, R. E. 1898: Northward over the "Great Ice”. 1, 521 pp. New York: Frederick A. Stokes.

Peel, J. S. 1978: Geological investigations in Lower Palaeozoic terrain of northern Greenland between $78^{\circ} 30^{\prime} \mathrm{N}$ and $81^{\circ} 30^{\prime} \mathrm{N}$. Rapp. Grønlands geol. Unders. 90, 14-16.

Troelsen, J. C. 1950: Contributions to the geology of Northwest Greenland, Ellesmere Island and Axel Heiberg Island. Meddr Grønland 149,7, 86 pp.

\title{
Field work on Precambrian anorthosite and contact rocks, Smithson Bjerge, Inglefield Bredning, North-West Greenland
}

\begin{abstract}
A. Nutman
This report gives an account of geological investigations and 1:25000 scale mapping of Precambrian rocks of Smithson Bjerge, at the head of Inglefield Bredning, about $150 \mathrm{~km}$ north-east of Thule Air Base. Previous work on this area was restricted to a few days of reconnaissance work in 1971 and several helicopter landings in 1975 (Dawes, 1972, and personal communication, 1978). Table 1 gives the principle geological events of the area and results of the mapping are given in outline in fig. 8 .
\end{abstract}

\section{Geological Divisions \\ Qaqujârssuaq anorthosite}

The northern half of the area is underlain by a generally uniform anorthosite body. Hornblende, locally with cores of pyroxene, is the dominant ferromagnesian mineral, garnet also occurs locally. The ferromagnesian minerals often occur with fine-grained plagioclase as groundmass to recrystallised plagioclases 5 to $50 \mathrm{~mm}$ in diameter, a relation interpreted as a relict igneous texture. Cyclic variation in the proportions of ferromagnesian mineral content is fairly common, giving the rock a moderately well-defined compositional banding.

More than 90 per cent of the anorthosite complex is true anorthosite, the remainder being leucogabbro and subordinate gabbro. Leucogabbro is most abundant about 1 to $2 \mathrm{~km}$ from 
Table 1. Principle geological events of the Thule area

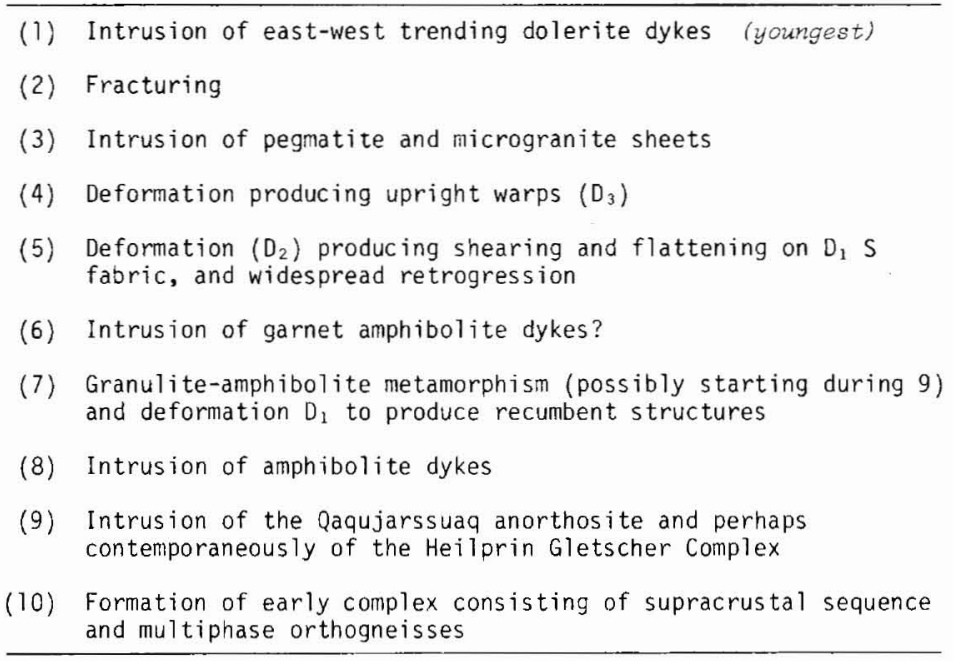

the southern boundary of the complex where it forms discontinuous horizons up to $100 \mathrm{~m}$ thick. Alternations of anorthosite and leucogabbro are normally stratiform, but blocks of anorthosite up to $2 \mathrm{~m}$ across occur locally in leucogabbro and vice versa. Some leucogabbro horizons show colour-index grading, but there is no obvious pattern in the facing of the grading. Some of the field relations listed above suggest that crystal accumulation processes operated during the crystallisation of the anorthosite. The leucocratic aspect of the rocks at the southern contact suggests that this is the upper margin of the anorthosite body on Smithson Bjerge.

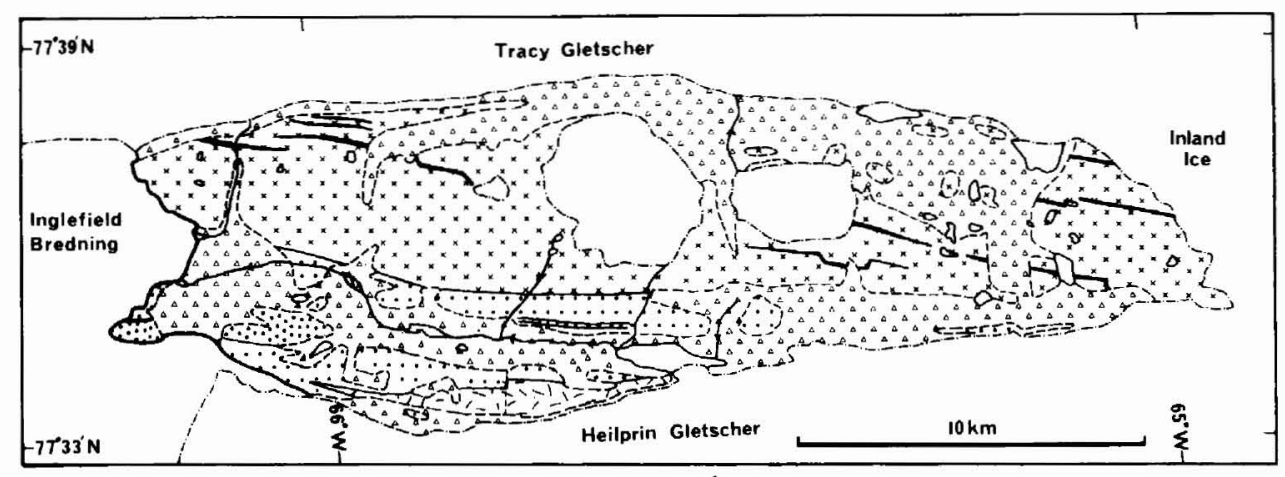

GEOLOGICAL SKETCH MAP OF SMITHSON BJERGE (QAQUJÂRSSUAQ)

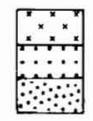

Anorthosite Supracrustals Heilprin Gletscher complex

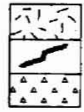

Multiphase orthogneiss Dolerite Cover

Fig. 8. Geological sketch map of Smithson Bjerge, Inglefield Bredning, North-West Greenland. 
Amphibolite dykes

Hundreds of discontinuous, melanocratic amphibolite dykes, usually less than $1 \mathrm{~m}$ thick, intrude the anorthosite as sporadically distributed swarms. A few similar dykes cut the metasedimentary rocks and orthogneisses south of the anorthosite. Dykes are often irregular with cuspate margins or flame-like apophyses, a morphology suggesting a low ductility contrast between the host and the magma at time of emplacement. Elsewhere lithologically similar dykes with regular margins are discordant to primary compositional banding in the anorthosite, indicating a rigid host. Both varieties of dyke pre-date development of foliation during early recumbent folding.

Several amphibolite dykes, up to $15 \mathrm{~m}$ thick, occur near the southern margin of the anorthosite. These have unfoliated, garnet amphibolite cores and flaggy, non-garnetiferous margins. They are regarded as younger than the early recumbent folding.

\section{Envelope rocks}

Orthogneisses and supracrustal rocks occur south of the Qaqujârssuaq anorthosite and are referred to collectively as the envelope rocks to the anorthosite.

\section{Supracrustal rocks}

Half of the envelope rocks are supracrustal rocks which may correlate with supracrustal rocks overlying basement gneisses on the north side of Inglefield Bredning (P. R. Dawes, personal communication, 1978). They form a well-layered sequence with compositional banding usually in the range of 0.1-2 $\mathrm{m}$.

Commonest lithologies are pelitic and semipelitic gneisses with quartz+feldspar + biotite + garnet \pm sillimanite or hypersthene mineralogy. Graphite was occasionally observed. Ironstones in discontinuous horizons (up to $20 \mathrm{~m}$, but usually less than $2 \mathrm{~m}$ thick) form less than 5 per cent of the sequence. 'Silicate facies' ironstones, with quartz+garnet+iron oxide + hornblende \pm hypersthene \pm iron sulphide mineralogy are dominant.

\section{Multiphase orthogneisses}

Tonalitic and granodioritic multiphase orthogneisses form a large unit in the south of the area. There is general parallelism of boundaries between different phases due to the original mode of formation of the complex by successive horizontal sheeting and also due to tectonic flattening. Most of the gneisses are resinous brown and have granulite facies mineralogy.

The multiphase gneiss - supracrustal rock boundary is straight for $10 \mathrm{~km}$, but due to non-exposure of the actual contact, its nature is uncertain. In the cliffs along the southern margin of the area multiphase orthogneisses alternate with supracrustal rocks. The nature of the relationship between the supracrustal rocks and multiphase orthogneisses will be discussed in detail elsewhere.

\section{Heilprin Gletscher Complex}

Intimately associated acid and basic meta-intrusive rocks form the Heilprin Gletscher Complex which intrudes supracrustal rocks in the south and west of the area. This complex may correlate with the Kap York meta-igneous complex (Dawes, 1975). Although generally 
highly deformed, components of the complex are locally well-preserved. Three main phases of injection, all closely related in time, were identified in the Heilprin Gletscher Complex; ferrodiorite/gabbro, pink granite and fine-grained leuco-amphibolite/diorite.

In areas of low deformation the ferrodiorite/gabbro locally shows igneous layering of similar attitude to layering in host supracrustal rocks, suggesting intrusion of the parent magma as subhorizontal sheets. Granulite facies cores are locally preserved in basic rocks of the complex. Where least deformed, the pink granite is porphyritic, with randomly orientated alkali feldspar megacrysts up to $2 \mathrm{~cm}$ long. Deformation progressively transforms the granite into a flaggy pale gneiss. This granite could be equivalent to deformed granites on Harward Øer (Dawes, 1976).

The ferrodiorite/gabbro occurs as enclaves in, or is intersheeted with, the pink granite, suggesting that the multiphase orthogneisses belong to this suite. Of infrequent occurrence, but widespread, are thin dykes of pyroxene-garnet-bearing, apatite-rich leuco-amphibolite/diorite that post-date the other lithologies of the Heilprin Gletscher Complex.

\section{Relationship between the anorthosite and its envelope}

In the supracrustal rocks close to the anorthosite there is an increase in amount of pegmatite neosome and a decrease in distinction of the compositional banding, which finally disappears apart from disrupted ironstone horizons. Mafic lithologies comparable with those of the Heilprin Gletscher Complex occur at the anorthosite contact where they may be gradational with, intruded by, or intrusive into the anorthosite. This variety of relations suggests almost contemporaneous intrusion of the Qaqujârssuaq anorthosite and the Heilprin Gletscher Complex. Locally, polymict igneous breccias occur at the contact, blocks of diorite and gabbro and rusty banded gneisses occuring in an anorthosite matrix. This igneous brecciation pre-dates the early recumbent folding. Inhomogeneous orthogneisses containing blebs of anorthosite occur locally. These relations are interpreted as being due to back-veining of envelope rocks into the anorthosite. A few ironstone enclaves also occur in the anorthosite near to the contact. These relations suggest that the boundary between the anorthosite and envelope rocks is igneous (however it is locally tectonised).

\section{Late minor intrusions}

Undeformed pink microgranite and pegmatite sills and north-south trending dykes occur sporadically throughout the area. East-west trending, slightly altered, dolerite dykes with chilled margins were intruded later. The dolerite dykes are non-porphyritic with a sub-ophitic texture in their centres. Locally they exploit pre-existing fractures with a general north-south trend.

\section{Quaternary deposits}

Quaternary silts with ice-rafted boulders form a platform in the west of the area. Assemblages of foraminifera from these silts indicate a cold, shallow water, marine to brackish environment, with some specimens possibly being transported to the site of deposition (J. W. Murray, personal communication, 1979). 
Structural and metamorphic history

All lithologies apart from late minor intrusions are intensely deformed and have amphibolite or granulite facies mineral assemblages, although incomplete retrogression under greenschist facies conditions is widespread. The earliest recognisable phase of deformation $\left(D_{1}\right)$ gave rise to recumbent structures with east-west trending fold axes, and LS tectonites. $\mathrm{D}_{1}$ was synchronous with high grade metamorphism. $\mathrm{D}_{2}$ at lower grades, with retrogression, gave rise to flattening and shearing on the $D_{1} \delta$ fabric. Late minor upright warps $D_{3}$ with north-south trending axes, deform earlier fabrics. $D_{1}$ resulted in intense flattening except in the hinges of $D_{1}$ folds. Stretching in the $D_{1}$ fold axial direction is indicated by a mineral lineation and elongation of 'tennis ball' plagioclases in leucogabbro into rods coaxial with $\mathrm{D}_{1}$ fold axes. As the anorthosite-envelope boundary occurs in the hinge of one or more $\mathrm{D}_{1}$ structures, primary relationships have escaped severe $D_{1}$ flattening. The sense of these and other $D_{1}$ structures indicate closure of a large $D_{1}$ structure 'upwards to the south'.

Amphibolite facies minerals grew during $\mathrm{D}_{1}$, but at present it is uncertain whether granulite facies assemblages are older than or synchronous with $\mathrm{D}_{1}$.

The final structural event gave rise to joints and minor faults including a north-south set and a conjugate system whose orientation suggests the maximum compressive stress was orientated north-south.

\section{Acknowledgements}

I thank Peter Dawes (GGU) and Erik Arnholtz of Thule Air Base for radio contact and assistance with practical problems. My thanks also go to the staff of the Geofysisk Observatorium Qânâq, and Qânâq hospital.

\section{References}

Dawes, P. R. 1972: Precambrian crystalline rocks and younger sediments of the Thule district, North Greenland. Rapp. Grønlands geol. Unders. 45, 10-15.

Dawes, P. R. 1975: Reconnaissance of the Thule Group and underlying basement rocks between Inglefield Bredning and Melville Bugt, North Greenland. Rapp. Grønlands geol. Unders. 75, 34-38.

Dawes, P. R. 1976: 1:500 000 mapping of the Thule district, North-West Greenland. Rapp. Grønlands geol. Unders. 80, 23-28.

Geology Department, The University, Exeter, Devon EX4 $4 Q E$, U.K. 